Article

\title{
The Problem of Evil and the Grammar of Goodness
}

\section{Eric Wiland}

Department of Philosophy, University of Missouri-St. Louis, One University Blvd, St. Louis, MO 63121, USA; wiland@umsl.edu

Received: 5 January 2018; Accepted: 20 January 2018; Published: 31 January 2018

\begin{abstract}
I consider the two venerated arguments about the existence of God: the Ontological Argument and the Argument from Evil. The Ontological Argument purports to show that God's nature guarantees that God exists. The Argument from Evil purports to show that God's nature, combined with some plausible facts about the way the world is, guarantees (or is very compelling grounds for thinking) that God does not exist. Both presume that it is coherent to predicate goodness (or greatness) of God. But if Peter Geach's claim that goodness is logically attributive is cogent, then both arguments fall to the ground.
\end{abstract}

Keywords: god; evil; goodness; religion

1. Here I consider two venerated arguments about the existence of God: the Ontological Argument and the Argument from Evil. The Ontological Argument purports to show that God's nature guarantees that God exists. The Argument from Evil purports to show that God's nature, combined with some plausible facts about the way the world is, guarantees (or is very compelling grounds for thinking) that God does not exist. Obviously, both arguments cannot be sound. But I argue here that they both are unsound for the very same reason.

2. Consider first the Argument from Evil. There are very many ways the Argument from Evil can be formulated. For the most part, these differences will not affect the issue at hand in this article. So here is one way of putting the Argument:

E1. If God exists, then a being who is all-powerful, all-knowing, and perfectly good exists.

E2. A being who is all-powerful, all-knowing, and perfectly good would not create a world in which there is (avoidable) evil.

E3. But there is (avoidable) evil in the world.

E4. God does not exist.

We are led to conclude that God does not exist, because if God did exist, then God would prevent the sorts of evils that we in fact see. We can be confident that God would prevent these evils, because that is what a perfectly good being who knew about these evils would do, if God could.

Consider next the Ontological Argument. There are many ways this argument can be formulated, but most of the differences between them will not affect the issue at hand in this article. (One variation is important. I will have something to say about this later.) Here is one rough but standard way the Ontological Argument is put:

O1. God is that than which no greater can be conceived.

O2. If God does not exist, then there is something greater than God that can be conceived.

O3. God exists. 
We are led to conclude that God exists, because it is part of the very concept of God that God is as great as one can possibly be, and that existence is part of greatness. We can be confident that God exists, because we know that a being that can be conceived and actually exists is greater than a being that merely can be conceived but does not exist.

Notice that both arguments rely on premises involving the nature of God, and that both attribute evaluative properties to God. In the case of the Argument from Evil, we are to think that God is good. In the case of the Ontological Argument, we are to think that God is great. Here I will question whether it is correct to think about God this way. ${ }^{1}$

3. Why think that there is anything amiss in saying that God is good or great? It will be instructive as a point of comparison to briefly review the history of one of the most influential arguments in moral philosophy, G. E. Moore's Open Question argument, an argument whose cogency depends entirely upon the logical grammar of goodness. Moore held that it always makes sense to ask, of any natural property, whether something that has that property is good. ${ }^{2}$ From this fact, Moore concluded that goodness is not identical with any natural property; for if the two were indeed identical, then it would not always make sense to ask whether something that has that natural property is good.

The lesson that Moore took away from this observation is that since goodness is not a natural property, it must be a nonnatural property. Noncognitivists, by contrast, typically conclude that goodness is, strictly speaking, not a property at all, and so moral language is to be understood as used to do something other than describing how the world is. ${ }^{3}$ And Cornell realists point out yet another option: they argue that the Open Question argument does not rule out the possibility of a posteriori necessary moral truths, and so goodness might still be a natural property after all. ${ }^{4}$

But one typically overlooked response to the problem Moore poses originates in the work of Peter Geach. ${ }^{5}$ Geach draws our attention to two different ways adjectives can logically function. Borrowing some terms from grammar, Geach distinguishes what he calls "predicative adjectives" from "attributive adjectives". Predicative adjectives attribute the possession of an independently identifiable property to the object of the adjective. Most adjectives seem to function as predicative adjectives. Consider color concepts. Because 'white' is predicative, the fact that the Washington Monument is a white building strictly implies that the Washington Monument is white. The noun that the adjective is modifying in the original claim can be dropped, and the adjective still can be truly predicated of the subject. (More formally, if $\mathrm{F}$ functions as a predicative adjective, then " $\mathrm{x}$ is a F K" implies that " $\mathrm{x}$ is $\mathrm{F}$ ".)

But this sort of implication is not available in the case of the use of every adjective. Attributive adjectives modify the object of the adjective by specifying a way of being that kind of object. As a result, the adjective cannot be meaningfully and correctly detached from the specific generic noun it modifies. The adjective 'large' works this way. The fact that $Y$ is a large microprocessor does not strictly imply that $\mathrm{Y}$ is large. The fact that $\mathrm{Z}$ is a heavy atom does not imply that $\mathrm{Z}$ is heavy. And, most importantly, the fact that N.N. is a good robber does not imply that N.N. is good. Attributive adjectives always, at least implicitly, need an associated generic noun to modify in order even to make sense. That is, we do sometimes say things like "Fido is large", this without explicitly mentioning any common noun. But context usually indicates that we do mean some common noun: we mean "Fido is a large dog" rather than "Fido is a large animal" or "Fido is a large noisemaker."

Note that we can 'trade' predicative adjectives in a way that we cannot attributive adjectives. If something is a white monument, and it is also a structure, then it must be a white structure.

\footnotetext{
1 Those who conceive of God as a perfect being nevertheless often understand this perfection to be a form of goodness. So what I say here about goodness also applies to the view that God is an Anselmian perfect being.

(Moore 1903).

(Stevenson 1944).

(Boyd 1988).

(Geach 1956).
} 
But if something is a small whale, and it is also an animal, then it is not necessarily a small animal. Whether something counts as small depends upon the kind of thing it is modifying.

Mistakenly detaching attributive adjectives from the generic nouns to which they attach often results in contradictions. For it might both be true that a particular painting is a genuine van Meegeren and a fake Vermeer (to use a standard example). Yet it is nothing but confusion to say that some particular painting is both genuine and fake. Terms like 'genuine' and 'fake' mean something only when they at least implicitly modify some noun.

Now Geach proposed that the adjectives 'good' and 'bad' always function attributively. Nothing is simply good or bad, but instead is a good or bad instance of some kind or other. If N.N. is a good robber, and also a person, N.N. is not thereby a good person. And that is because there just is no property of goodness that can be identified independently of a goodness-fixing kind.

If Geach is right, then Moore was incorrect to hold that it always makes sense to ask, in response to the claim that some object has some natural property, whether it is also simply good. Rather, it never makes sense to ask of some object simply whether it is good (at least not unless the context implicitly makes some kind salient). That would be like asking whether it is large or heavy or genuine. Nothing is simply good. We can sensibly ask only whether something is a good K (where K denotes some generic kind), and then the answer to that question essentially depends upon what kind of thing is under discussion.

This is obviously so in the case of artifacts. It makes no sense just to say baldly that some particular object is good; rather, it makes sense to say that it is a good (or bad) music player, or a good (or bad) doorstop, or a good (or bad) theft deterrent, or a good (or bad) anniversary present, and so on. Something can be a good or bad instance of its kind (which themselves can be multiple), but nothing is good or bad tout court.

What does Geach's account of the grammar of goodness imply about morality? There are many possibilities, but his account fits very nicely with a view of morality developed by Elizabeth Anscombe, Philippa Foot, and Michael Thompson. ${ }^{6}$ On this view, whether some operation or state of yours is good or bad depends upon the kind of creature you are. It would be a defect in me were I not to care for my offspring. Ignoring one's offspring is a bad human action. This has to do with natural facts about human beings. But it is not a defect in each and every fish were they not to care for their offspring. In their case, ignoring one's offspring is not a bad operation (at least for some species of fish). What counts as a good or bad operation depends crucially upon the kind of creature operating.

There are facts about how human beings live and operate, facts that set the standard of goodness for particular human beings. For instance, it is a natural fact that human beings have ten fingers. But Uncle Joe here has only six fingers. He is, for all that, a human being; but to that extent he is deformed or disabled. He is at least missing four fingers. It might not be a defect in some particular creature of some other kind to have six fingers, but it is for humans.

These natural facts are neither merely statistical nor purely normative. As Anscombe noted, human beings have thirty-two teeth, even if most of them do not. ${ }^{7}$ And to say 'humans beings have thirty-two teeth' is not merely to say that they should have thirty-two teeth. For I might say of a rotary saw blade that I am now forging that it should have thirty-two teeth, and I would mean something very different by that utterance than I mean when I say that human beings have thirty-two teeth. In the case of the saw-blade, it would specify what I, its creator, intend. For humans, however, it specifies what kind of thing a human being is. (We can see the distinction at work by imagining a surgeon who says of her patient: 'This man, whose kind has two legs, should, due to gangrene in his foot, have one leg.')

Now there are natural facts not only about the number of fingers or teeth humans have, but also natural facts about their wills. And to the extent that my will differs from this standard, my will is

(Anscombe 2006; Foot 2001; Thompson 1995).

(Anscombe 1958). 
thereby defective or bad. When we say that So-and-so is a (morally) bad person, we usually mean that So-and-so's will is a bad human will. Whether some feature or operation of me is a good or bad feature or operation never floats free of the kind (or kinds) of creature I am, but makes sense only in reference to this more general thing: my species.

I propose to take this account of goodness in general, and moral goodness in particular, very seriously. I admit that there are objections to this view, objections that merit careful consideration. Some of these objections seem prima facie powerful. This is not the place to weigh them, but I will head off a few misconceptions.

First, Geach's point is not about surface grammar. Very often, one says things like "That new Sopranos episode was good!", and everyone knows what one means. The listener typically has no trouble grasping that one means that it was a good episode, rather than a good soporific, or a good depiction of the typical American family.

Second, only some generic nouns imply standards of goodness. To say of some particular entity that it is a good molecule leaves one's listener scratching her head. For there is no such thing as a good molecule or a bad molecule, not without some special story about what one needs a particular kind of molecule for-in which case the relevant generic noun is not simply a molecule, but something more specific than that. Some but not all nouns are 'goodness-fixing kinds' ${ }^{8}$

Third and finally, it is possible to agree with Geach in the main, but understand remaining stubborn predicative uses of the word 'good' expressivistically. While most surface predicative uses of the word 'good' can be understood by implicitly inserting some appropriate generic noun to which it is attached, we may interpret other predicative uses of 'good' as noncognitivists do. If Ellen says "That is good!", and she rejects all of our attempts to insert some generic noun into her thought ("A good party?" "A good meeting?"), then we should probably take her merely to be expressing her positive emotions about the subject of her sentence. While we can reject noncognitivism about most uses of evaluative predicates, such an account may be appropriate for other uses of them.

4. Now suppose Geach's view here is correct: goodness is a two-place relation between a particular and a kind, a kind of which the particular is a member. What follows from this account?

I will initially argue that (1) God is not a member of any kind; then, more modestly; (2) God is not a member of any kind that has standards of goodness internal to it; then, finally and sincerely; (3) God is not a member of any kind that has standards of goodness internal to it such that God would be defective with respect to said standards by failing to prevent suffering. (Similar claims about greatness will hold as well.)

First, consider the claim that God is not a member of any kind. There is no kind K of which God is a particular member. God is necessarily sui generis, which amounts to the claim that God isn't a member of any generis at all. On one conception of the divine, a particular god might be a member of the kind gods. This may be the proper way to understand certain mythological polytheisms. We might think that Mars, for instance, is a particularly good or bad god, because he has or lacks most of the characteristics gods have. But many theists can reply that God is instead utterly unique, without thereby committing any severe heterodoxy. Nor is God's uniqueness contingent, as is the uniqueness of, say, a particular British Guiana 1c magenta stamp, a kind of which there could have been more than one. God's uniqueness, by contrast, is necessary, a member of no genuine kind. And if there is no kind $\mathrm{K}$ of which God is a particular member, then, on the Geachean view of goodness, God cannot be a good (or bad) K.

It may be objected that there are indeed some true things that can be said about God. For instance, God has existed for more than four minutes. So God is a member of the kind of things that have existed for more than four minutes, just as you and I are. Thus it appears false to say that God is not a member of any kind whatsoever. 
Nonetheless, this is not enough to establish what is needed for the Argument from Evil to work. This kind (more-than-four-minute-existents) does not give rise to any standards according to which a particular entity could be a good or bad instance of its kind. There is no such thing as a bad or good more-than-four-minute-existent. Any particular entity that has not existed for more than four minutes is not a bad more-than-four-minute existent. So while God may be a member of some kinds, God is not a member of any kind that has standards of goodness internal to it.

But it may now be objected that God is indeed a member of a kind that has standards of goodness internal to it. By any orthodox account, God is an intelligent being. An intelligent being is good qua intelligent being, in so far as it is knowledgeable, logical, and has all the other intellectual virtues. So it is indeed possible for God to be a good or bad intelligent being. Thus, the objector concludes, there are indeed standards of goodness that apply to God. ${ }^{9}$

Still, this is not enough to rescue the Argument from Evil. It is true that God would be a bad intelligent being by failing to be clever or rational or critical. God is indeed a member of some kinds that have standards of goodness internal to them. But even so, God is not a member of any kind for which alleviating avoidable suffering counts as a defect. That is, God is not a member of any kind of entity good instances of which must prevent avoidable suffering. So the kinds to which God does belong do not require eliminating our woes in order to be a good instance of those kinds. The fact that God can be a good K for some Ks does not mean God would thus wipe the world of pain and suffering.

Some will want to insist that God, like all humans, is a member of the class of Rational Beings, and as a result God is governed by exactly the same rules of rationality as are humans, and that these rules imply, among other things, that God should prevent suffering, and so on. I don't want to deny that God is a rational being. And I concede that if rationality alone demanded preventing avoidable suffering, my argument would fall to the ground. But there is little reason to think that rationality or rational agency demands this. A few philosophers have claimed that rationality itself indeed requires one to prevent avoidable suffering, ${ }^{10}$ but all these arguments, alas, fail. ${ }^{11}$ Rationality alone may require some things of agents-e.g., taking the necessary means to one's ends, deliberating in light of all the available evidence-but it does not require one to prevent avoidable suffering. Only a specific form of benevolence requires that.

The most important implication of this line of argument is that we have no grounds for saying that if God is good, God will not create a world in which there is suffering. For the antecedent, strictly speaking, makes no sense. God cannot be good or bad tout court, in just the same way that the number 3 cannot be good or bad, or that the set of molecules constituting this volume cannot be good or bad. Premises E1 and E2 are neither true nor false, but are ill-formed. And thus the Argument from Evil is not a sound argument.

My proposal here differs from classic responses to the problem of Evil. Some see a way out by radically altering what is meant by 'God'. Others, for instance, have thought that God has no interests or desires or aims, and that this is one reason why it does not make sense to say that God is good, for goodness is always relative to these things. But nothing I have said commits me to the thought that God is without interests or desires or aims. All I have held is that God is not a member of any kind whose goodness as a member of that kind requires one to minimize suffering.

Likewise, some have proposed what is called negative theology, the view that we can say only what God is not, not anything about what God is. Others have argued that God is hidden, and we just do not know why God would permit suffering unnecessarily. This may be true, but it too differs from what I have been arguing. We may know exactly what God is like. My proposal really requires no major revision in the traditional conception of God, only a revision in the common (but mistaken) conception of the grammar of goodness.

\footnotetext{
I thank George Streeter for raising this objection.

10 See (Korsgaard 2009; Smith 2015).

11 See (Enoch 2006) and Wiland (2012), among many other rebuttals.
} 
My argument also differs from many recent responses to the Argument from Evil. It is not based upon the claim that evil is a result of the free will of human beings. ${ }^{12}$ It is not based upon a theodicy of soul-making. ${ }^{13}$ It does not depend upon the claim that suffering unifies us with God. ${ }^{14}$ It does not cast doubt upon the thought that animals experience genuine suffering. ${ }^{15}$ It does not depend upon (but does naturally cohere with) the thought that there is no best possible world. ${ }^{16}$

My argument does resemble Mark Murphy's recent response to the Argument from Evil. ${ }^{17}$ We both agree that it is not true that God ('an Anselmian being') is ethically bound to promote the well-being of others. That is, even if it is ethically required for you and me to come to the aid of others, it isn't ethically required of God. Murphy concludes that the "argument from evil against the existence of an Anselmian being is effectively defanged by a proper understanding of the ethics of the Anselmian being" (p. 103).

I too think that a proper understanding of God-and of the nature of evaluative and ethical concepts—defangs the argument from evil. But my reasons are very different from Murphy's. Murphy still thinks that some sort of ethics applies to God; it's just not the same sort of ethics that apply to everyone else. By contrast, I'm calling into question the well-formedness of the very thought that God (or anything) can be judged to be good simpliciter. Only members of certain kinds can be evaluated, and God is not a member of any kind for which it is a defect not to prevent suffering. So, although we arrive at similar conclusions, Murphy's argument and my argument take very different paths to get there.

Even if I am correct that there are no standards of goodness or badness that apply to God, the problem of evil may return in some other form. Instead of predicating goodness of God, one might predicate omnibenevolence of God. The existence of evil seems to imply that there is no omniscient, omnipotent, omnibenevolent being. Does this show that God does not exist?

I do not think so. There is no reason for insisting that if God exists, God is omnibenevolent. Most religious traditions do hold that God sometimes acts benevolently. But these traditions (apart from their theologians) do not supply grounds for insisting that God must always does the most benevolent thing. God may be selectively benevolent, but not omnibenevolent. So shifting the focus from God's goodness to God's omnibenevolence will not enable to us to infer that God does not exist.

I concede it remains unclear why we should worship a being who does not always alleviate avoidable suffering. One might sensibly wonder why we should submit to the will of a being who could easily improve our lives, and yet sometimes does not. Although I do not have a solution to this problem, I suspect the most promising strategy is to focus not upon God's intrinsic nature (omnipotence, omniscience, etc.), but upon other relations between God and us. That is, even if God doesn't alleviate all of our suffering, God may still treat us in other ways that make God a worthy object of our worship. Not all ways of being worthy of worship involve abating suffering. Different religious traditions will spell out what makes someone worthy of worship in different ways. ${ }^{18}$ Here, I merely assume that there might be some ways that God is related to us to be worthy of our worship.

I have suggested a way theists can reply to the Argument from Evil, a way to block the argument that God does not exist. The solution is heterodox in so far as I do not maintain that God is good. But we are still entitled to say that God is free of defect. God is without flaw. God is in no respect bad. Maybe that is all the orthodoxy we need.

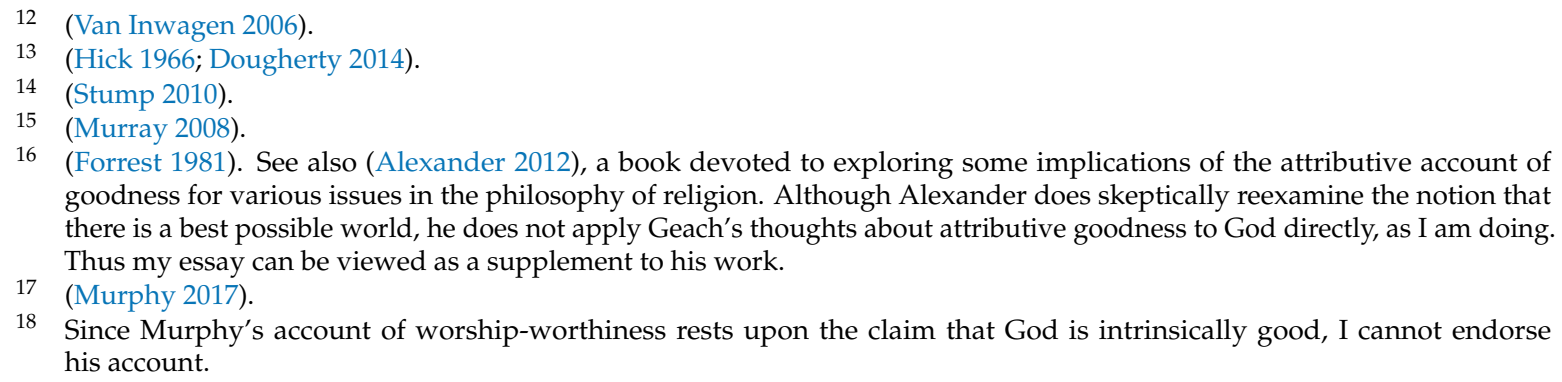


5. The Ontological Argument suffers from similar problems, and here I will be even briefer. It begins by understanding God as great (or perfect); in fact, God is the greatest thing that can be conceived. This presumes that it make sense to say (baldly) that God is great. But is this correct?

I venture to say that all of the reasons for thinking that 'good' always functions attributively apply with equal force in favor of thinking that 'great' and 'perfect' always functions attributively. We often do say that something is (just plain) great, but this is usually because we expect the listener to use contextual cues to understand some generic noun as relevant. If Nicolas says "Beethoven was great", we presume that he means that Beethoven was a great composer, not a great joke-teller. When Muhammad Ali said "I am the greatest", we should not expect his confidence to waver if someone were to point out that there is an awfully large wall in China. Asking whether the Great Awakening was greater than the Great Depression misses the point. Greatness, like goodness, always logically functions attributively.

We do sometimes compare the greatness of one kind of thing with the greatness of a different kind of thing. People sensibly argue over whether Tiger Woods is greater than Michael Jordan, despite the fact that one is a golfer and the other is a basketball player (we should ignore Jordan's mediocre golfing and baseball careers). But this is only because (1) they are both athletes, and (2) it makes sense to talk of a great athlete. Such comparisons are possible only when the items that are being compared all fall under some category that implies criteria for being great. Not all categories do imply criteria of greatness: it makes no sense to speak of a great way of exerting a gravitational force. Thus it makes no sense to say that something is great unless some generic noun is thereby implied, or we are to understanding the locution in an expressivist fashion.

And so it is not true that God is great, much less greater than anything else conceivable. Premises $\mathrm{O} 1$ and $\mathrm{O} 2$ are not true, not because they are false, but because they are ill-formed. The Ontological Argument seemed to work only because it had appeared to make sense to say that God was great. Once we see that this does not make sense, the appeal of the Ontological Argument evaporates.

Can the Ontological Argument be revised so that it is sound? The most immediate way to repair the argument may be to find some kind of which God is a great instance. The theist will likely first try:

O1* God is that than which no greater being can be conceived.

$\mathrm{O}^{*}$ If God does not exist, then there is some greater being than God that can be conceived.

O3* God exists.

At least this argument uses 'great' attributively. Or it pretends to. For to say that one item is a greater being than another item merely amounts to saying that the first item is greater than the second item, which is to say nothing at all: being a being brings no specific criteria of greatness in tow. ${ }^{19}$ In order to repair the Ontological Argument, one needs to find some specific generic noun of which God is the greatest possible instance. ${ }^{20}$

Perhaps we can do that. God is a great creator. God is a great provider. These are specific aspects of the orthodox notion of God. So consider:

$\mathrm{O}^{* *}$ God is that than which no greater provider can be conceived.

19 See Geach (1956, p. 41): " 'Event', like 'thing', is too empty a word to convey either a criterion of identity or a standard of goodness; to ask 'Is this a good or bad thing (to happen)?' is as useless as to ask 'Is this the same thing that I saw yesterday?' or 'Is the same event still going on?', unless the emptiness of 'thing' or 'event' is filled up by a special context of utterance."

20 What is true of 'great' is also true of 'perfect', and so versions of the Ontological Argument formulated in terms of perfection face the same problem. What do a perfect gentleman, a perfect sphere, a perfect game, and perfect pitch all have in common? They have no kind-relative defects. A perfect game is a game whose pitcher allows no baserunners. A perfect sphere is an object whose shape deviates in no way from that of a sphere. What substantively makes a game a perfect game, and what substantively makes a sphere a perfect sphere, overlap not at all. As with 'good' and 'great', 'perfect' is arguably always an attributive adjective. And just as 'being' is not a goodness-fixing or a greatness-fixing kind, 'being' is not a perfection-fixing kind. Thus perfect-being theologies depend upon a mistaken conception of the concept of perfection. See, for example, (Rogers 2000). 
$\mathrm{O} 2 * *$ If God does not exist, then there is some greater provider than God that can be conceived.

O3** God exists.

Is this argument sound? A problem emerges. First, it is not obvious that a provider who exists is ipso facto a greater provider than a provider who does not, this for two reasons. First, it is arguable that existence is not really a perfection. ${ }^{21}$ Second, even if existence is a good-making feature, consider explicitly who is the greater provider: Santa Claus, or my Uncle Daniel, who once gave me $\$ 10$ for my birthday? It's true that Uncle Daniel exists, whereas Santa Claus does not. But Santa Claus gives presents to millions of children, while my Uncle Daniel is exceedingly flinty. The second consideration seems to outweigh the first. One provider is not always a greater provider than another provider simply because only the first one exists.

Still, perhaps a provider who exists is ceteris paribus a greater provider than one does not. And God is not simply a great provider. God is purportedly the greatest provider whom can be conceived. So maybe the argument is sound.

But is it true that God is the greatest provider that we can conceive? Is O1** true? I can conceive of a being who is exactly like God (call this being Schmod), except that (1) Schmod just provided me with a proof of the Goldbach Conjecture (or some other wanted thing that I have not in fact been provided with), and (2) Schmod does not in fact exist. Still, Schmod would seem to be an even greater provider than the greatest provider who actually exists. Or, if providing me with a proof of the Goldbach Conjecture is alone not enough to make Schmod a greater provider than the greatest provider who actually exists, then we can imagine Schmod also providing me and others with all sorts of things that no one actually provides us with. This should be enough to make Schmod a greater provider than the greatest provider who actually exists, much like Santa Claus is a greater provider than my Uncle Daniel. So O1** is false. And it appears that analogous moves could be made with any other generic noun that is inserted (in place of "provider") in the argument. ${ }^{22}$

Here's a second problem with the revised argument. Even if my argument of the previous paragraph fails, the revised argument shows only that greatest conceivable provider exists. It permits us to conclude nothing else about the nature of the being in question; in particular, we are not permitted to conclude that such a being has all the other characteristics typically attributed to God, such as omniscience-at least not unless it can also be shown that the greatest possible knower exists. So it is highly unlikely that the Ontological Argument can give the theist everything she wants. Still, I must confess that the Ontological Argument is less damaged by the logic of evaluative adjectives than is the Argument from Evil.

One might worry that while I have rejected some traditional definitions of 'God' (e.g., the best possible being, the greatest possible being), I have not offered an alternative definition. So, in what sense have I really shown that the theist can avoid the Argument from Evil? What exactly does a theist believe in? ${ }^{23}$ Here I am deliberately underspecifying the nature of God, this so as to be maximally open to the widest range of theologies. I aim to exclude only those theologies whose claims about God are not well-formed. I assume that there are many coherent forms of theism. But, I acknowledge, I have not here shown that there are.

Furthermore, early on I hinted that there was a variation of the Ontological Argument that was importantly different from the version of it I consider here. This version is formulated not at all in terms of God's greatness, but instead in terms of God's necessity. ${ }^{24}$ The thought behind these modal arguments is roughly that God, by definition, is not a contingent being. So if is possible that God exists, it is necessary that God exists. But it is possible that God exists. So God exists. Whether this argument

\footnotetext{
See here (Lindeman 2017).

2 This argument obviously bears affinities with Gaunilo's objections to one of Anselm's versions of the ontological argument. I thank an anonymous reviewer for raising this worry in particular, and for many other helpful suggestions.

(Malcolm 1960; Plantinga 1965). If, however, some version of the modal argument is itself based upon the notion that God is good or perfect, the original problem reemerges.
} 
is sound is a controversial matter; I raise it only to acknowledge that the logic of evaluative adjectives has no bearing upon it.

6. Evaluative adjectives such as 'good' or 'great' logically function as attributive adjectives, a fact that proponents of two standard arguments concerning the existence of God have overlooked to their own detriment. Many have been too quick to assume that we can determine whether God exists by exploring what good particulars of other sorts are like. But a good or great instance of one kind and a good or great instance of another kind need have nothing else in common. So reasoning analogically about God in these ways is likely to falter.

Conflicts of Interest: The author declares no conflict of interest.

\section{References}

Alexander, David. 2012. Goodness, God, and Evil. London: Continuum Press.

Anscombe, Gertrude Elizabeth Margaret. 1958. Modern Moral Philosophy. Philosophy 33: 1-19. [CrossRef]

Anscombe, Gertrude Elizabeth Margaret. 2006. Good and Bad Human Action. In Human Life, Action and Ethics. Exeter: Imprint Academic, pp. 195-206.

Boyd, Richard N. 1988. How to be a Moral Realist. In Essays on Moral Realism. Edited by G. Sayre-McCord. Ithaca: Cornell University Press, pp. 181-228.

Dougherty, Trent. 2014. The Problem of Animal Pain: A Theodicy for All Creatures Great and Small. Basingstoke: Palgrave Macmillan.

Enoch, David. 2006. Agency, Shmagency: Why normativity won't come from what is constitutive of agency. Philosophical Review 115: 169-98. [CrossRef]

Foot, Philippa. 2001. Natural Goodness. Oxford: Oxford University Press.

Forrest, Peter. 1981. The problem of evil: Two neglected defences. Sophia 20: 49-54. [CrossRef]

Geach, Peter. 1956. Good and Evil. Analysis 17: 33-42. [CrossRef]

Hick, John. 1966. Evil and the God of Love. Basingstoke: MacMillan.

Korsgaard, Christine. 2009. Self-Constitution: Action, Identity, and Integrity. Oxford: Oxford University Press.

Lindeman, Kathryn. 2017. Constitutivism without Normative Thresholds. The Journal of Ethics and Social Philosophy 12: 231-57. [CrossRef]

Malcolm, Norman. 1960. Anselm's Ontological Arguments. Philosophical Review 69: 41-62. [CrossRef]

Moore, George E. 1903. Principia Ethica. Cambridge: Cambridge University Press.

Murphy, Mark C. 2017. God's Own Ethics: Norms of Divine Agency and the Argument from Evil. Oxford: Oxford University Press.

Murray, Michael J. 2008. Nature Red in Tooth and Claw: Theism and the Problem of Animal Suffering. Oxford: Oxford University Press.

Plantinga, Alvin. 1965. The Ontological Argument from St. Anselm to Contemporary Philosophers. New York: Doubleday. Rogers, Katherin. 2000. Perfect Being Theology. Edinburgh: Edinburgh University Press.

Smith, Michael. 2015. The magic of constitutivism. American Philosophical Quarterly 52: 187-200.

Stevenson, Charles L. 1944. Ethics and Language. New Haven: Yale University Press.

Stump, Eleonore. 2010. Wandering in Darkness: Narrative and the Problem of Suffering. Oxford: Oxford University Press. Thompson, Michael. 1995. The Representation of Life. In Virtues and Reasons. Oxford: Oxford University Press, pp. 247-96.

Thomson, Judith Jarvis. 2003. Goodness and Advice. Princeton: Princeton University Press.

Van Inwagen, Peter. 2006. The Problem of Evil. Oxford: Oxford University Press.

Wiland, Eric. 2012. Reasons. London: Continuum Press.

(C) 2018 by the author. Licensee MDPI, Basel, Switzerland. This article is an open access article distributed under the terms and conditions of the Creative Commons Attribution (CC BY) license (http://creativecommons.org/licenses/by/4.0/). 